\title{
Adaptasi Pelaksanaan Mata Kuliah Studio Perancangan Arsitektur dan Desain Interior di Perguruan Tinggi Indonesia pada Masa Pandemi
}

\author{
Feni Kurniati $^{1}$, Vika Haristianti ${ }^{2}$, Stefani Natalia Sabatini ${ }^{3}$ \\ 1. Arsitektur, Sekolah Arsitektur, Perencanaan, dan Pengembangan Kebijakan, Institut Teknologi \\ Bandung, Jl. Ganesha 10, Bandung \\ 2. Desain Interior, Fakultas Industri Kreatif, Universitas Telkom, \\ J1. Telekomunikasi, Bandung \\ 3. Arsitektur, Fakultas Arsitektur dan Desain, Universitas Kristen Duta Wacana, \\ Jl. dr. Wahidin Sudirohusodo No. 5-25, Yogyakarta \\ Email: ${ }^{1}$ fenikurniati@gmail.com, ${ }^{2}$ haristiantivika@telkomuniversity.ac.id, \\ ${ }^{3}$ stefanisabatini@staff.ukdw.ac.id
}

\begin{abstract}
Abstrak
Pandemi telah menyebabkan adanya perubahan pelaksanaan kelas Mata Kuliah Studio di Program Studi Arsitektur dan Desain Interior. Saat ini, pelaksanaan studio secara daring pada semester gasal 2019-2020 telah berlangsung selama empat bulan. Penelitian ini bertujuan untuk mengidentifikasi perubahan pelaksanaan Mata Kuliah Studio Perancangan di masa pandemi Covid-19 serta imbasnya pada capaian pembelajaran di akhir semester. Metode analisis yang digunakan adalah analisis kuantitatif. Pengumpulan data dilakukan dengan cara pembagian kuesioner daring kepada dosen pengampu kelas Mata Kuliah Studio Perancangan di Perguruan Tinggi Indonesia. Adapun pengambilan sampel dilakukan dengan menggunakan tipe non-random atau purposive sample. Hasil analisis menunjukan bahwa dari 82 sampel yang didapatkan, mayoritas menggunakan metode blended learning (sinkronus dan asinkronus). Pada akhir perkuliahan studio perancangan ditemukan bahwa mahasiswa mengalami beberapa perubahan capaian yang signifikan terkait pemahaman dan kesadaran ruang serta kemampuan digital, dan perubahan yang tidak signifikan terkait kemampuan presentasi, dan keterbangunan desain, sedangkan pada sisi kreativitas mahasiswa tidak mengalami perubahan capaian. Lebih lanjut, temuan ini dapat menjadi basis pertimbangan dalam melakukan perubahan substansi tugas untuk format studio daring.
\end{abstract}

Kata kunci: studio perancangan, pembelajaran daring, arsitektur, desain interior, pandemi.

\section{Abstract \\ Title: Adaptation on the Implementation of Architecture and Interior Design Studio from the Universities in Indonesia}

The pandemic has caused a change in the implementation of Studio courses in the Architecture and Interior Design Study Program. Currently, the online studio implementation in the odd semester of 2019-2020 has been going on for four months. This study aims to identify changes in the implementation of the Design Studio Course in the Interior Design and Architecture Study Program during the Covid-19 pandemic and its impact on learning outcomes at the end of the semester. The analytical method used is quantitative analysis. Data collection was carried out by distributing online questionnaires to class lecturers of Design Studio Course at Indonesian Universities. The sampling was done using a non-random or purposive sample type. The results of the analysis showed that of the 82 samples obtained, the majority used the blended learning method (synchronous and asynchronous). At the end of the design studio lecture, it was found that students experienced several significant changes in achievement related to understanding and awareness of space and digital capabilities, and insignificant changes related to presentation skills, and design constructability, while in the creativity skills, students do not experience any significant changes. Furthermore, these 
findings may be used as the basis to create future adjustments in the setting of architectural online learning.

Keywords: design studio, online learning, architecture, interior design, pandemic.

\section{Pendahuluan}

Sejak bulan April 2020, Pemerintah Indonesia telah menetapkan kebijakan lockdown dan karantina di berbagai daerah untuk memutus mata rantai penyebaran virus Covid-19. Penerapan kebijakan ini menyebabkan berbagai kegiatan kantor dan sekolah harus dilakukan dari rumah, dengan istilah yang dikenal sebagai work from home dan school from home. Perguruan tinggi termasuk salah satu instansi yang terkena dampak, sehingga harus menutup kampus dan menerapkan sistem belajar jarak jauh (https://www.kompas.com/edu/read/2020/06/16/103917571/mendikbudperguruan-tinggi-di-semua-zona-dilarang-kuliah-tatap-muka, diakses 19 Oktober 2020).

Pandemi Covid-19 dipercaya telah mempercepat proses perpindahan pendidikan ke sistem daring, yang dulunya sering memperoleh penolakan khususnya di bidang arsitektur dan desain interior, yang bertumpu pada sistem studio perancangan sebagai core utama. Menurut Mostafavi (2020), salah satu hal yang menyebabkan arsitektur dan desain interior sangat sulit meninggalkan sistem kelas konvensional adalah model pembelajaran studio yang sangat bergantung pada interaksi langsung dalam kelompok kecil, hands-on model maket, dan komunikasi interaktif dalam proses desain (https://www.designboom.com/architecture/mohsen-mostafavifuture-architectural-education-09-04-2020, diakses 16 Juni 2020). Dengan demikian, pelaksanaan studio yang tadinya tatap muka harus diubah menjadi tatap layar (daring). Hal ini tentu saja mengubah metode dan media pengajaran, target, serta capaian mahasiswa lulusan studio tersebut.

Saat ini, mata kuliah studio perancangan di perguruan tinggi Indonesia telah dilaksanakan secara daring pada semester ganjil 2019-2020 yang telah berlangsung selama empat bulan hingga penelitian ini dilakukan. Penelitian ini bertujuan untuk mengidentifikasi perubahan dalam pelaksanaan Mata Kuliah Studio Perancangan pada Program Studi Desain Interior dan Arsitektur di masa pandemi Covid-19, serta dampaknya terhadap capaian pembelajaran di akhir semester.

Secara umum, pelaksanaan Mata Kuliah Studio Perancangan pada Program Studi Arsitektur dan Desain Interior sesuai dengan teori Dodsworth \& Anderson (2015), bahwa desain terdiri dari proses analisis, development, thinking on paper dan implementasi. Metode ini juga sejalan dengan pengaplikasian double diamond design process oleh Design Council yang terdiri dari proses discover, define, develop, deliver seperti pada Gambar 1 di bawah ini. 


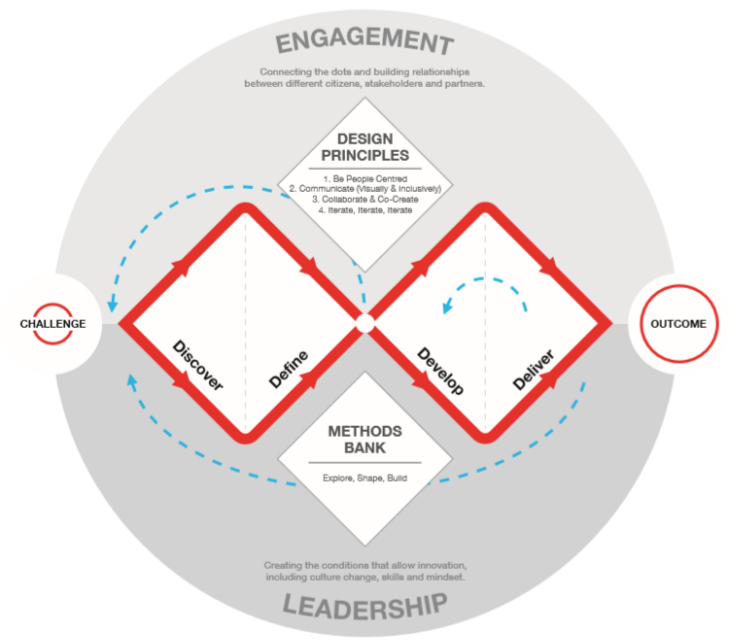

Gambar 1. Double diamond design model

Sumber: https://www.designcouncil.org.uk/news-opinion/what-framework-innovation-designcouncils-evolved-double-diamond, diakses 7 September 2020

Dalam prosesnya, mahasiswa dan dosen pengampu di kelas mencoba secara terstruktur menjalankan tahapan-tahapan desain tersebut pada proyek yang dikerjakan. Agar hal tersebut dapat berjalan dengan lancar, serta mahasiswa dapat menghasilkan desain yang baik, diperlukan aspek komunikasi dan kejelasan dalam pelaksanaan pengajaran di kelas.

Pada kondisi normal, di kelas Mata Kuliah Studio Perancangan biasanya pengajaran dilakukan dengan menerapkan banyaknya sesi diskusi dan asistensi antara mahasiswa dengan dosen dan asisten dosen, maupun antar sesama mahasiswa. Namun, semenjak pandemi terjadi dan kuliah diadakan secara daring, pertemuan diskusi dan asistensi tatap muka harus berubah sehingga dosen pengampu mau tidak mau harus merubah metode pengajaran secara mendadak dan cukup signifikan. tujuannya adalah agar target capaian pembelajaran tetap dapat dicapai dengan baik. Karena adanya fenomena perubahan metode pembelajaran ini, ada beberapa isu yang penulis tangkap telah terjadi pada pelaksanaan pembelajaran Mata Kuliah Studio Perancangan di masa pandemi, yaitu:

\section{Isu Ketersediaan Perangkat dan Kemampuan Daring}

Isu ini menjadi penting untuk dibahas karena perubahan metode belajar dari luring menjadi daring sangat bergantung terhadap ketersediaan perangkat (secara sarana maupun media) dan kemampuan dosen pengampu serta mahasiswa menjalankan software atau tools untuk dijadikan alat komunikasi pengganti sistem asistensi secara langsung.

\section{Isu Performa Akademik}

Perubahan metode pembelajaran tentu saja secara langsung atau tidak langsung akan dikaitkan dengan hasil akhir. Pada kasus pembelajaran Mata Kuliah Studio Perancangan, di akhir semester dosen pengampu dan mahasiswa tetap harus dapat menyelesaikan proyek yang ditentukan berdasarkan dengan capaian pembelajaran 
yang dituju. Isu performa akademik menjadi layak diperbincangkan dikarenakan Performa akademik akan sangat berpengaruh pada setiap tahapan double diamond.

\section{Isu Psikologis}

Adanya perubahan metode yang mendadak pastilah tidak hanya berpengaruh terhadap perubahan cara pembelajaran, lebih jauh akan menyentuh isu psikologis. Untuk itu, isu ini pun menjadi layak untuk diperbincangkan.

Intinya, paper ini bertujuan untuk mengidentifikasi perubahan pelaksanaan Mata Kuliah Studio Perancangan pada Program Studi Desain Interior dan Arsitektur di masa pandemi Covid-19 serta imbasnya pada capaian pembelajaran di akhir semester dengan menjadikan ketiga poin di atas sebagai variabel yang dibahas. Hasil penelitian diharapkan dapat menghasilkan pemetaan sejauh mana perubahan terjadi, serta dampak positif dan negatif yang dirasakan. penelitian ini diharapkan dapat menjadi masukan untuk perkembangan Mata Kuliah Studio Perancangan di Program Studi Arsitektur dan Desain Interior.

\section{Metode Penelitian}

Penelitian ini merupakan penelitian awal yang bertujuan untuk menggali pengetahuan terkait dampak pelaksanaan studio perancangan secara daring yang merupakan pengalaman pertama bagi para pendidik (dosen) di bidang Arsitektur dan Desain Interior di Indonesia. Dosen dipilih sebagai target responden karena beberapa alasan. Pertama, dosen adalah pihak pertama yang merespon perkuliahan daring melalui penyesuaian desain materi dan kurikulum sehingga target capaian tetap terpenuhi. Kedua, dengan asumsi satu dosen menangani sejumlah mahasiswa, maka informasi yang diperoleh juga akan lebih banyak karena tidak hanya mewakili diri sendiri, namun juga mahasiswa bimbingannya. Dengan demikian, sebagai penelitian pemula, maka dosen dipilih sebagai fokus awal untuk membangun pengetahuan awal terkait topik online learning ini.

Penelitian ini menggunakan pendekatan kuantitatif, baik untuk metode pengumpulan data dengan menggunakan kuesioner, maupun metoda analisis yang menggunakan teknik analisis distribusi frekuensi.

\section{Metode Pengumpulan Data}

Pengumpulan data dilakukan dengan cara membagikan kuesioner secara daring kepada para dosen Arsitektur dan Desain Interior yang terlibat dalam Mata Kuliah Studio Perancangan. Adapun tipe pemilihan sampel menggunakan tipe sampel nonrandom/purposive sampling (Kumar, 2005). Responden yang mengisi kuesioner daring adalah Dosen Pengampu yang mengajar Mata Kuliah Studio Perancangan Arsitektur dan Desain Interior pada Perguruan Tinggi di Indonesia saat masa pandemi berlangsung. Jika dilihat dari diagram persebaran, sampel berasal dari total 82 dosen dari 37 perguruan tinggi yang tersebar di 20 kota Indonesia (lihat Gambar 1). 82 dosen ini merupakan dosen jurusan arsitektur dan desain interior dengan perbandingan 80\%:20\% (lihat Gambar 2). 


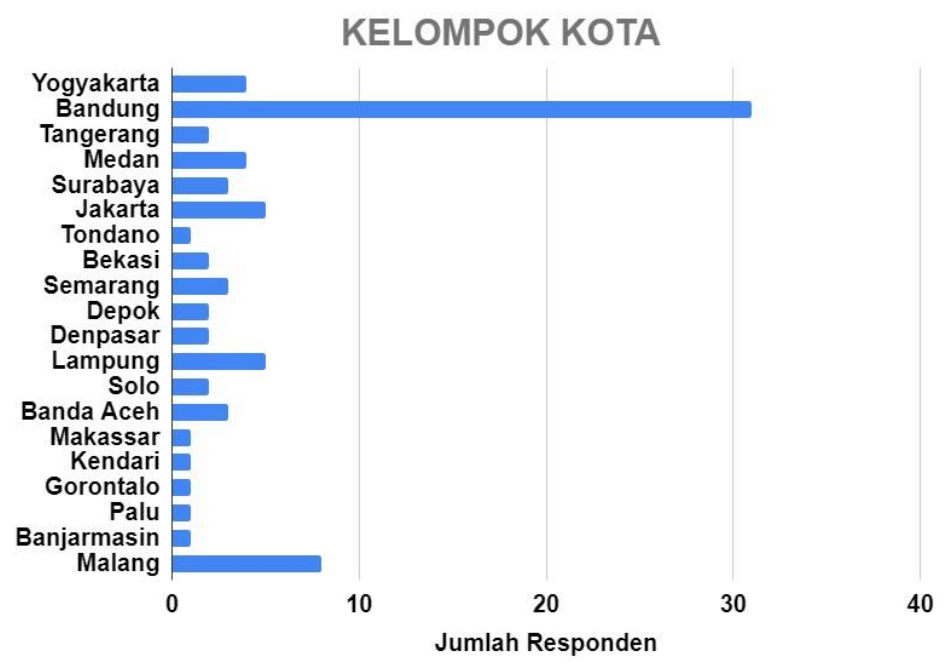

Gambar 2. Sebaran kota sampel data Sumber: Hasil kuesioner, 2020

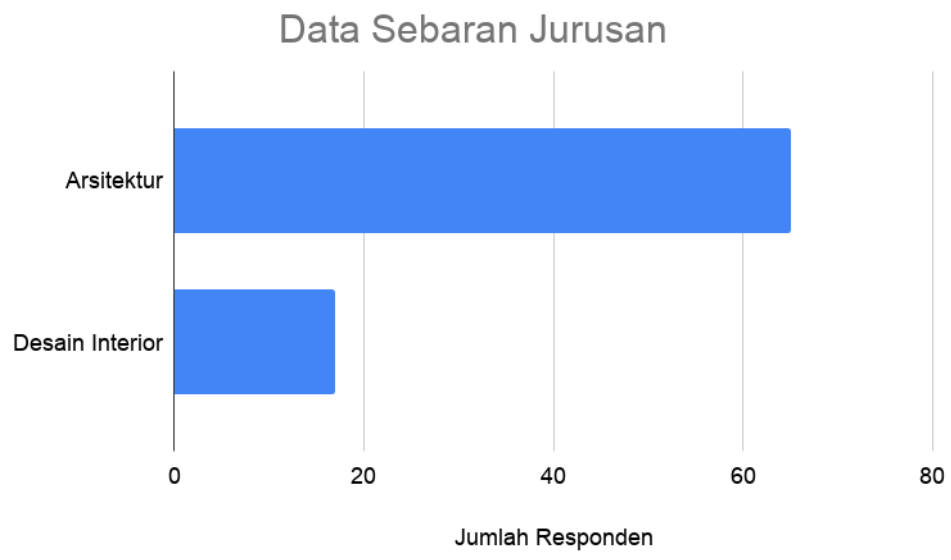

Gambar 3. Sebaran jurusan responden Sumber: Hasil kuesioner, 2020

\section{Metode Analisis Data}

Data diolah secara kuantitatif. Hasil pengisian kuesioner diubah ke dalam diagram distribusi frekuensi. Lalu, hasil dari diagram tersebut diinterpretasikan menjadi deskripsi berdasarkan data pendukung hasil wawancara.

\section{Hasil dan Pembahasan}

Pandemi Covid-19 telah berhasil mempercepat proses perpindahan sistem pendidikan ke media daring, termasuk bidang Arsitektur dan Desain Interior. Arsitektur dan Desain Interior, yang merupakan bidang keilmuan yang sangat mengandalkan media berupa model atau maket sebagai media representasi ide, budaya studio dengan kelompok kecil, dan pengalaman merasakan ruang secara 
langsung, terpaksa harus mulai melepaskan diri dari tatanan tersebut dan beradaptasi terhadap sistem pembelajaran baru, yaitu daring.

Dalam proses adaptasinya, pelaksanaan studio perancangan daring telah merubah berbagai hal. Dari 1 semester kuliah daring yang telah berlangsung sejak pandemi, perhatian yang paling besar dirasakan dari aspek komunikasi. Berubahnya media komunikasi dari tatap muka menjadi tatap layar juga berakibat pada performa pihak-pihak yang terlibat, baik dosen maupun mahasiswa.

Tulisan ini akan membahas 3 aspek yang dinilai paling mengalami perubahan saat terjadi perpindahan dari pengajaran luring, menjadi daring. ketiga aspek tersebut berkaitan dengan ketersediaan dan kemampuan menggunakan perangkat, performa akademik dan juga psikologis dosen dan mahasiswa. Secara lebih jelas, kami jelaskan ke dalam beberapa pembahasan berupa interpretasi hasil kuesioner di bawah ini:

\section{Ketersediaan dan Kemampuan Menggunakan Perangkat Daring}

Dari survei yang telah dilakukan terhadap 82 dosen dari 37 perguruan tinggi yang terlibat dalam pengajaran studio perancangan secara daring di Indonesia, ditemukan bahwa sebagian besar kampus telah mengadopsi penggunaan media daring baik untuk proses penyampaian materi, proses asistensi maupun bentuk keluaran tugas.

Berdasarkan Gambar 3, dapat dilihat bahwa dari aspek keluaran tugas yang diminta, lebih dari $50 \%$ responden telah mengadopsi sistem daring secara menyeluruh seperti gambar dan poster digital. Sementara itu, 36,6\% responden menggunakan media campuran antara daring dan luring, sedangkan $11 \%$ sisanya masih mengandalkan sistem luring sepenuhnya dengan menggunakan gambar tangan dan maket.

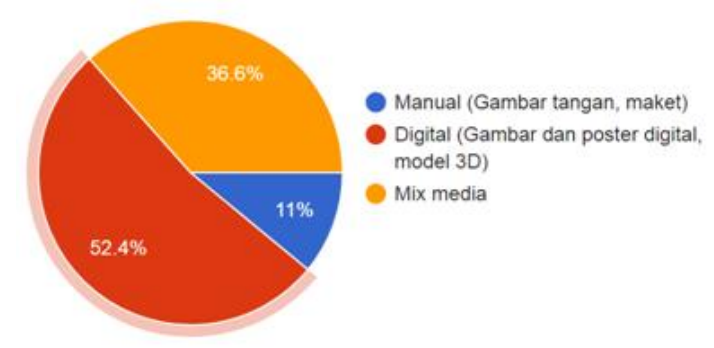

Gambar 4. Diagram media pengumpulan Tugas Akhir Sumber: Hasil kuesioner, 2020

Penggunaan media manual dalam pelaksanaan studio perancangan daring ini ditemukan pada responden yang terlibat dalam studio perancangan semester 2, yang merupakan studio awal bagi mahasiswa arsitektur yang menitikberatkan pada kemampuan menyampaikan gagasan arsitektural melalui berbagai teknik dasar presentasi grafis (gambar dan sketsa) dan model maket. Hal ini menunjukkan bahwa bahwa secara kurikulum, setiap Perguruan Tinggi yang menjadi responden telah memiliki sistem pengajaran dan aturan yang mirip. Terlepas dari lokasi yang berbeda dan tersebar di beberapa provinsi dan pulau di Indonesia. Dengan kata lain, 
setiap perguruan tinggi menunjukkan kemampuan beradaptasi yang relatif sama dalam menghadapi kondisi pandemi dan perkuliahan jarak jauh.

\section{Sistem Pengajaran}

Dari survei yang telah dilakukan terhadap 82 dosen dari 37 perguruan tinggi yang terlibat dalam pengajaran studio perancangan secara daring di Indonesia, ditemukan bahwa sebanyak 55 responden $(67.1 \%)$ melakukan sistem pengajaran blended learning, 20 responden $24.4 \%$ melakukan sistem pembelajaran asinkronus (tidak langsung), dan 7 responden (8.5\%) melakukan sistem pembelajaran sinkronus (langsung). adapun data persebarannya dapat dilihat pada Gambar 5 di bawah ini:

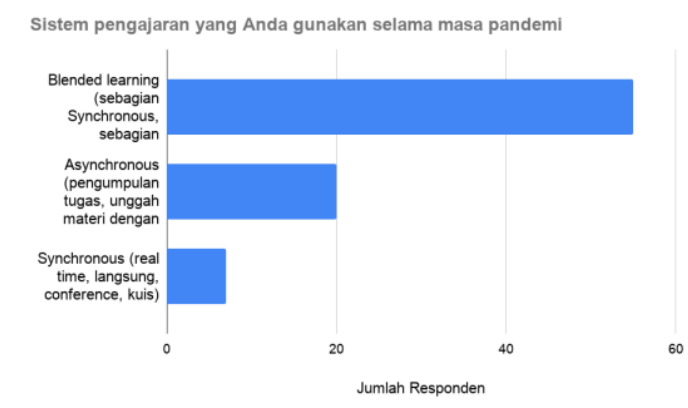

Gambar 5. Sistem pengajaran yang dilakukan Sumber: Hasil kuesioner, 2020

Dari diagram di atas dapat dijelaskan bahwa mayoritas memilih sistem blended learning karena memungkinkan untuk pengajar dan mahasiswa menjalankan berbagai jenis metode pembelajaran, fleksibilitas dalam pengumpulan tugas serta proses asistensi. Sistem blended learning dianggap sebagai sistem terbaik dan terdekat dengan kondisi pelaksanaan Mata Kuliah Studio Perancangan sebelum adanya masa pandemi.

\section{Performa Akademik}

Dengan berubahnya media pembelajaran studio perancangan dari sistem luring ke daring, maka aspek komunikasi yang menjadi bagian utama dari proses belajarmengajar menjadi aspek penting yang perlu ditelaah untuk dapat memetakan sejauh mana performa dosen dan mahasiswa terdampak dari perubahan ini. Dalam studi ini, terdapat 2 aspek yang diamati yaitu: 1) beban kerja dan durasi waktu yang harus dialokasikan dosen dan 2) capaian mahasiswa dalam studio.

Penggunaan media daring seperti video conference dan instant messenger, serta penggunaan metode syncronous dan asyncronous dalam pengajaran studio ditemukan juga mempengaruhi beban kerja dosen sebagai pengajar mata kuliah tersebut. Dari data yang berhasil dikumpulkan, perubahan yang ditemukan cukup beragam (lihat Gambar 6). 


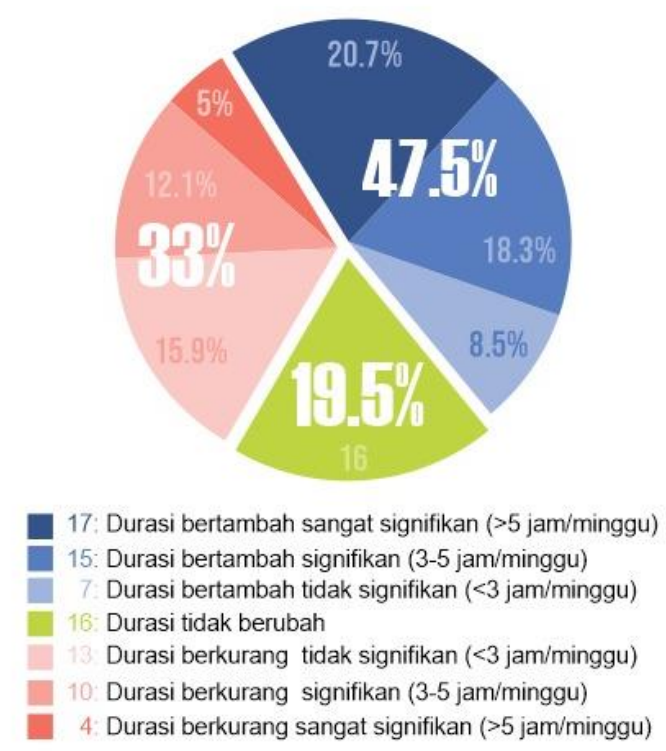

Gambar 6. Perubahan durasi asistensi pada mata kuliah Studio Perancangan pasca pandemi Sumber: Hasil kuesioner, 2020

Berdasarkan Gambar 6, ditemukan bahwa sebagian besar responden mengalami bertambahnya durasi pelaksanaan studio sebesar $47,5 \%$, sedangkan yang durasi berkurang sebesar $33 \%$ dan selebihnya $(18,5 \%)$ menyatakan tidak terjadi perubahan durasi.

Dari 47,5\% responden dengan durasi pengajaran bertambah, 20,7\% menyatakan bertambah $>5$ jam, 18,3\% bertambah 3-5 jam dan 8,5\% bertambah 1-3 jam. Secara umum ditemukan bahwa sejak studio daring, durasi bertambah sangat signifikan dengan nilai signifikansi sebesar 2,3. Hal ini Menunjukkan bahwa komunikasi dan interaksi antara mahasiswa dan dosen secara daring menjadi lebih lama dibandingkan dengan sistem luring yang sebelumnya terjadi di dalam ruang studio. Dengan kata lain, perpindahan ke metode daring dengan bantuan berbagai platform video conference dan email/instant messenger membuat batas-batas fisik ruang dan waktu menjadi lebur. Dalam hal ini, sistem daring memberikan peluang bagi mahasiswa dan dosen untuk saling menjangkau dan berkomunikasi terlepas dari batas kaku terkait ruang dan waktu pelaksanaan tatap muka studio.

Sementara itu, ditemukan juga bahwa sebesar 33\% responden menyatakan berkurangnya durasi studio sejak menggunakan sistem daring (5\% berkurang $>5$ jam, 12,1\% berkurang 3-5 jam dan 15,9\% berkurang 1-2 jam). Dari ketiga kategori ini ditemukan bahwa secara umum durasi berkurang secara tidak signifikan dengan nilai $-1,6$ saja.

Berkurangnya durasi pada pelaksanaan studio ini ditemukan pada responden yang memiliki keterbatasan akses terhadap fasilitas daring, baik dari perangkat lunak (jaringan internet) maupun perangkat keras seperti hanya menggunakan smartphone saja. Di samping itu, juga ditemukan indikasi bahwa ketersediaan subsidi kuota untuk pelaksanaan studio daring menjadi sangat penting dalam menentukan berkurangnya jumlah tatap layar antara dosen dan mahasiswa. Hal lain 
yang juga menjadi variabel penting terkait perubahan ini adalah kurangnya kontrol sosial dari sesama dosen. Ruang-ruang virtual ini telah menghapus adanya pertemuan fisik yang sebelumnya menjadi peluang bagi dosen untuk dapat saling berbagi informasi terkait progres dan saling menjaga kualitas capaian studio.

Selanjutnya, Gambar 6 juga menunjukkan bahwa terdapat 19,5\% responden yang menyatakan tidak ada perubahan durasi pertemuan studio perancangan. Dengan kata lain, meskipun sistem pengajaran telah berubah dari luring ke daring, ditemukan bahwa 16 dosen tetap menjaga jadwal dan durasi pertemuan sebagaimana yang telah biasa dilakukan sebelum masa pandemi. Hal ini juga dapat dipahami bahwa terdapat kesadaran untuk menjaga porsi beban dan ruang-ruang privasi bagi beberapa dosen tersebut, yang lebih jauh akan mempengaruhi capaian mahasiswa dalam Mata Kuliah Perancangan Studio Arsitektur (lihat Gambar 7).

Gambar 7 berikut ini menunjukkan dinamika perubahan capaian mahasiswa selama studio daring dilaksanakan. Secara garis besar, perubahan penguasaan kemampuan arsitektural mahasiswa tidak begitu signifikan (rata-rata dibawah 1), namun tetap ditemukan beberapa perubahan yang perlu digaris bawahi.

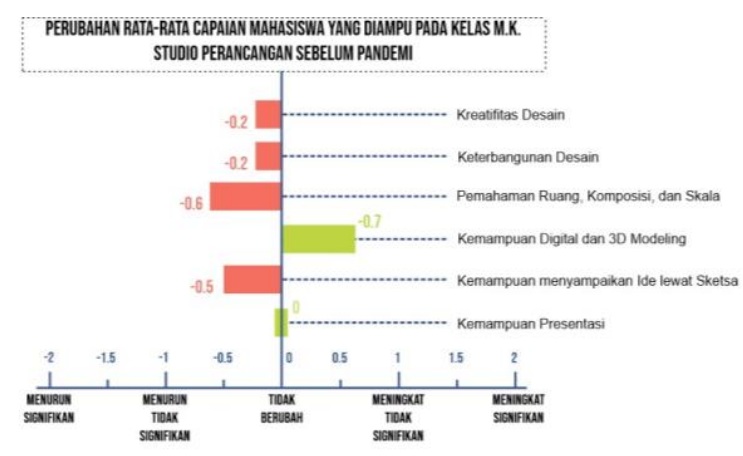

Gambar 7. Perubahan capaian mahasiswa pada mata kuliah Studio Perancangan pasca pandemi

Sumber: Hasil kuesioner, 2020

Kemampuan rata-rata presentasi lisan mahasiswa sejak diterapkannya studio daring dinilai cenderung tidak berubah (lihat Gambar 7) namun secara umum trennya cenderung meningkat tidak signifikan. Sementara itu, capaian terkait aspek kreativitas dan keterbangunan desain ditemukan cenderung tidak berubah sampai menurun secara tidak signifikan dengan nilai rata-rata -0,2. Penurunan kemampuan ditemukan lebih signifikan pada aspek pemahaman dan kesadaran ruang/skala dan kemampuan representasi ide melalui sketsa, dengan nilai rata-rata -0,6 dan -0,5. Berkurangnya kesadaran skala akan ruang disebabkan karena dihilangkannya kesempatan merasakan skala ruang secara langsung disebabkan karena adanya kebijakan pembatasan sosial berskala besar pada kota-kota di Indonesia menyebabkan sulitnya survey lapangan dilakukan. Sedangkan penurunan kemampuan sketsa (tidak signifikan) disebabkan karena perubahan bentuk tugas yang lebih menekankan pada produksi gambar digital untuk kemudahan proses pengumpulan dan asistensi. 
Sebaliknya, kemampuan digital ditemukan meningkat tidak signifikan. Hal ini dimungkinkan karena adanya perubahan pembuatan maket menjadi animasi $3 D$ modelling secara digital sehingga berdampak kepada tersedianya lebih banyak waktu dan tuntutan bagi mahasiswa untuk mengolah penugasan secara digital agar dapat mengejar output yang diharuskan. Lebih jauh, pembelajaran daring ini dapat memberikan peluang yang lebih luas bagi pendidikan arsitektur untuk mengadopsi dan mengintegrasikan pendidikan arsitektur dengan perkembangan teknologi seperti software perancangan dalam proses mendesain mahasiswa di mata kuliah studio.

\section{Aspek Psikologis}

Hal lain yang juga menjadi perhatian sejak diterapkannya pelaksanaan studio perancangan secara daring adalah aspek kesehatan mental para pengajar dan mahasiswa yang terlibat. Hal ini menjadi penting karena setiap perubahan yang dilakukan secara cepat dan mendadak akan berdampak pada kesiapan ataupun kemampuan manusia dalam beradaptasi terhadap perubahan tersebut.

Dari aspek psikologis mahasiswa, studi ini (Gambar 8) menunjukkan bahwa secara umum terjadi penurunan pada sikap dan attitude mahasiswa selama studio adring dilaksanakan, dengan penurunan rata-rata $-0,42$ (menurun cenderung tidak signifikan). Aspek yang dilihat mencakup tingkat kehadiran (-0,378), tingkat motivasi mengikuti perkuliahan $(0,378)$, produktivitas mengerjakan tugas $(-0,378)$ dan keterbukaan dalam proses asistensi/diskusi (-0,3). Selanjutnya, pada kemampuan mahasiswa berkonsentrasi menunjukkan adanya penurunan yang lebih signifikan, dengan nilai rata-rata sekitar dua kali dari penurunan pada aspek yang lainnya, yaitu $-0,682$.

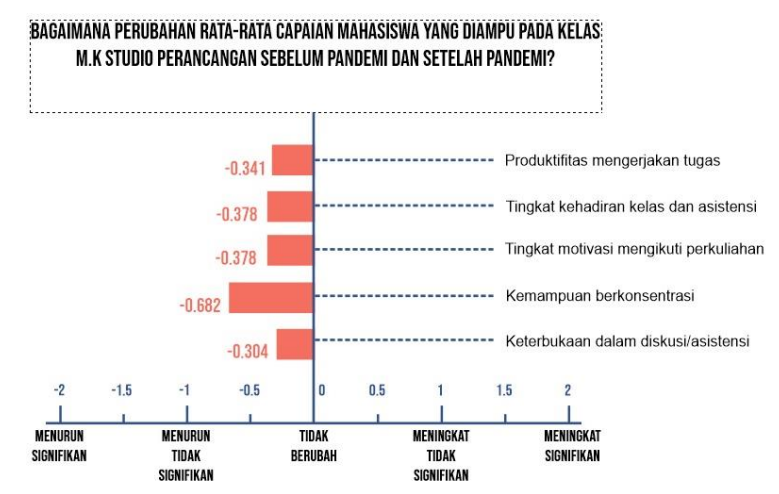

\section{Gambar 8. Perubahan capaian mahasiswa pada mata kuliah Studio Perancangan pasca pandemi}

Sumber: Hasil kuesioner, 2020

Penurunan yang ditemukan pada setiap aspek sikap dan psikologis mahasiswa pada studio daring ini menunjukkan bahwa adanya hal-hal yang hilang ketika studio dilaksanakan dari jarak jauh. Khususnya pada dinamika budaya studio yang menekankan pada komunikasi interaktif dan metode hands-on ketika eksplorasi maket, serta dinamika sosial dan dukungan moral sesama teman yang dirasakan ketika bekerja di ruang studio. Hal ini berarti bahwa support dan kesempatan belajar sesama teman yang sangat dinamis dan mengalir, yang biasanya diperoleh dari 
kehadiran selama di ruang studio, menjadi hilang karena batas-batas ruang virtual yang hadir. Dengan demikian, sistem daring menjadi pembatas arah-arah komunikasi yang terjadi, yang lebih merupakan satu arah dan terbatas. Kesempatan-kesempatan untuk saling belajar, saling mengamati pekerjaan satusama lain dan saling memberikan motivasi menjadi terbatas dalam pendidikan virtual sehingga mahasiswa mengalami demotivasi.

Sementara itu, dosen juga merasakan kendala selama proses adaptasi pelaksanaan studio daring. Gambar 9 menunjukkan bahwa rata-rata responden merasakan turunnya motivasi untuk bekerja $(-0,475)$, lebih mudah kelelahan dan depresi (0,548), serta lebih sulit untuk berkonsentrasi dengan sistem daring (-0,597), jika dibandingkan dengan sistem tatap muka di studio sebelumnya. Turunnya motivasi dan semangat dosen untuk melaksanakan studio daring ini disebabkan karena sering kali komunikasi yang terjadi dalam dunia virtual adalah satu arah, sehingga kesempatan dosen untuk terhubung dengan mahasiswa melalui observasi ekspresi, fokus dan perhatian mahasiswa menjadi sangat terbatas. Hal ini mempengaruhi attachment dan penghayatan dosen dalam menjalankan perannya sebagai pengajar maupun fasilitator.

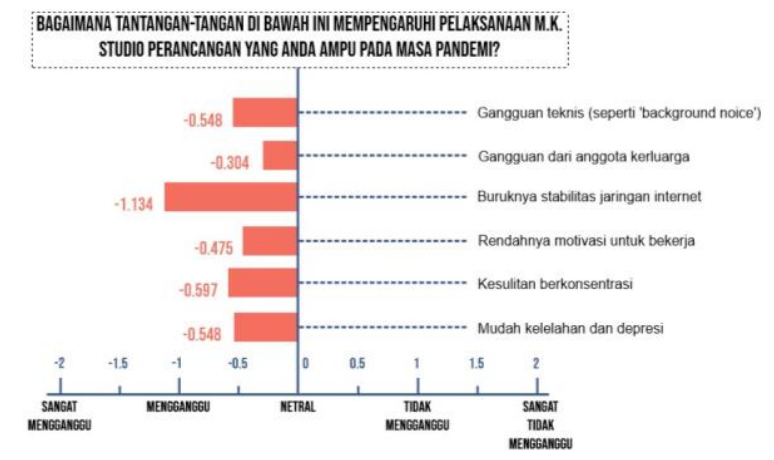

\section{Gambar 9. Pengaruh Tantangan Pelaksanaan Studio di Masa Pandemi}

Sumber: Hasil kuesioner, 2020

Di samping itu, penelitian ini juga menunjukkan bahwa selama pandemi dan online learning, dosen merasa lebih rentan terhadap rasa lelah dan depresi. Salah satu penyebab kondisi tersebut adalah buruknya stabilitas jaringan internet yang merupakan satu-satunya media untuk dapat terhubung dengan mahasiswa bimbingan (lihat Gambar 9). Selanjutnya, kendala lain yang juga dirasakan sangat mengganggu proses pengajaran studio online adalah gangguan teknis seperti perangkat yang tidak mendukung, background noise yang mengganggu, dan keberadaan anggota keluarga yang juga bekerja atau belajar dari rumah.

\section{Kesimpulan}

Pandemi Covid-19 telah memungkinkan terjadinya perubahan yang sangat cepat dalam sistem pendidikan arsitektur di Indonesia. Keengganan meninggalkan budaya studio untuk berpindah ke distance learning secara terpaksa harus berubah. Penelitian ini menunjukkan semua jurusan Arsitektur di perguruan tinggi di 
Indonesia telah melakukan adaptasi bentuk keluaran tugas dan sistem pengajaran studio ke dalam sistem daring, terlepas dari lokasi dan wilayah kampus tersebut.

Lebih jauh, adaptasi studio daring ini berdampak terhadap kinerja dosen dan performa akademik para mahasiswa. Dunia virtual yang mengaburkan batas-batas ruang dan waktu memungkinkan terjadinya komunikasi dan interaksi online di luar jam-jam studio yang telah ditentukan. Hal ini menyebabkan durasi dan beban kerja dosen secara signifikan meningkat. Sementara itu, terkait performa mahasiswa di studio, dinilai terjadi penurunan khususnya pada kemampuan dalam memahami ruang dan skala, serta kemampuan merepresentasikan gagasan arsitektural dalam sketsa dan gambar freehand. Di sisi lain, terjadi peningkatan kemampuan mahasiswa dalam menggunakan software $3 D$ modelling dalam merepresentasikan desain. Hal ini menunjukkan bahwa pendidikan arsitektur memiliki peluang untuk meningkatkan penggunaan teknologi $3 D$ modelling sebagai media berpikir desain bagi mahasiswa, tidak hanya sekedar tools dalam memproduksi gambar atau model.

Pola komunikasi online ini juga ditemukan membuat dosen dan mahasiswa menjadi sangat bergantung pada aspek-aspek seperti perangkat gadget, ketersediaan jaringan internet, dan kondisi lingkungan rumah. Munculnya berbagai faktor eksternal yang berada di luar kontrol diri, baik dosen dan mahasiswa ini, telah menimbulkan kerentanan terhadap depresi dan demotivasi dalam proses studio daring yang dilaksanakan di berbagai perguruan tinggi di Indonesia.

Di samping itu, mengingat singkatnya waktu sejak pelaksanaan studio daring hingga dilaksanakannya penelitian ini (4 bulan), maka sangat dimaklumi bahwa temuan-temuan ini bersifat temporal yang berarti bahwa respon yang diberikan masih berupa refleksi dari perkenalan awal yang singkat dengan sistem daring, yang tentu saja seiring berjalan waktu hingga kemudian tulisan ini disusun, berbagai perbaikan dan perubahan yang lebih responsif telah banyak dilakukan. Dengan demikian, diperlukan telaah lebih jauh terkait bentuk perubahan yang dilakukan telah dilakukan sejauh ini, tidak hanya dari segi teknik pelaksanaan, namun juga bentuk, pendekatan dan substansi materi dan tugas yang diberikan di studio.

\section{Daftar Pustaka}

Kumar, R. (2019). Research methodology: A step-by-step guide for beginners. London: Sage Publications Limited.

Dodsworth, S. \& Anderson, S. (2015). The fundamentals of interior design. London: Bloomsbury Publishing. 